\title{
Protestáns kultúrrégiók a 19. század első felében Az akadémiai csúcselit kollektív biográfiai elemzésének néhány társadalomföldrajzi tanulsága
}

\author{
Protestant cultural regions in the first half of the 19th century: \\ Some socio-geographical results of a collective biographical analysis \\ of the elite of the Hungarian Academy of Sciences
}

\section{UGRAI JÁNOS}

UGRAI János: habilitált egyetemi docens, Tokaj-Hegyalja Egyetem; 3950 Sárospatak, Eötvös u. 7.; ugraij@gmail.com; https://orcid.org/0000-0001-7200-3006

KULCSSZAVAK: szellemi elit; Akadémia; térbeli tagolódás; 19. század

ABSZTRAKT: Tanulmányunkban a reformkori Akadémia protestáns tagjainak földrajzi hovatartozását vizsgáltuk kollektív biográfiai eszközökkel. A tanulmányi pálya és a felnőtt életutak állomásait kultúrrégiókhoz soroltuk. Ezt követően a kultúrrégiók egymáshoz viszonyított arányát, akadémiai reprezentációjuk erejét, illetve a személyek kultúrrégiók közötti mozgását, földrajzi mobilitásuk nagyságát és intenzitását határoztuk meg.

A vizsgálatot az tette lehetővé, hogy a reformkori Akadémia különböző metszésvonalak mentén egyensúlyozó mechanizmusokat müködtetett, s így felekezeti és földrajzi értelemben is egyfajta reprezentativitásra törekedett. A nemzeti kibontakozás jegyében ráadásul nemcsak tudományos, hanem nyelv- és müvészetpártoló, müvelődésszervező célkitüzései is hangsúlyosak voltak. Ily módon nemcsak a tudományos, hanem a tágabban vett szellemi elit egészének összetételére érvényes következtetéseket vonhatunk le. A tanulmányban alkalmazott kultúrrégió kifejezés pedig az egyházi társadalomtörténetben már ismert „felekezeti-művelődési alakzat” kiterjesztésének, a térbeli tagolódás megjelenítésére alkalmas elágazásának tekinthető.

A reformkorban a Magyar Tudós Társaság tagjává választottak 28\%-a református, 12\%-a evangélikus volt. Mindkét felekezet felülreprezentált volt tehát az összlakosságban elfoglalt súlyához képest, de a felülreprezentáltság mértéke jellegzetes különbséget mutat. A reformátusok esetében ezzel a módszerrel is kimutatható Debrecen mint szellemi központ kimagasló ereje - és egyúttal erőteljes zártsága. Debrecenhez hasonló arányban delegált akadémikusokat az erdélyi református kultúrrégió, amely azonban nem kizárólag Kolozsvárhoz, hanem részben Nagyenyedhez és Marosvásárhelyhez kötötte a kulturális élet vezéreit. A decentralizáció jegyei a többi református kultúrrégióban is kimutathatóak. Az evangélikus kulturális csúcselit körében még jellemzőbb a decentralizáltság - ennek érzékletes példáját a hagyományos, legerősebb iskolaközpont, Pozsony látványos "gyengélkedése" szolgáltatja.

A református kultúrrégiók esetében szembeszökő, hogy hiába éltek jelentős arányban kálvinisták a Dél-Dunántúlon, az Alföld felén és Észak-Tiszántúlon, nem rendelkeztek olyan iskolavárossal, szellemi központtal, amely alkalmas lett volna legalább egy-két akadémikus kinevelésére. Mindez természetesen újra csak Debrecen egészen különleges szerepére világít rá. Ehhez képest másféle stratégia jellemezte az evangélikusokat, akiknek nemcsak észak-magyarországi érdekeltsége volt kiterjedt, de a Dél-Alföldön is rendelkeztek akadémiai kapcsolatokkal.

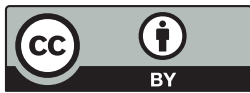


A reformkori akadémikusok mobilitását vizsgálva Debrecen és Erdély önállóságához (és zártságához) nyertünk újabb érveket, emellett pedig Pest immár egyre erőteljesebb vonzó hatása támasztható alá meggyőző számokkal.

János UGRAI: associate professor, University of Tokaj-Hegyalja; Eötvös u. 7., H-3950 Sárospatak, Hungary; ugraij@gmail.com; https://orcid.org/0000-0001-7200-3006

KEYWORDS: cultural elite; Hungarian Academy of Sciences in the Reform Era; spatial divisions; 19. century

ABSTRACT: The study examines the geographical origins of Protestant members of the Hungarian Academy of Sciences in the Hungarian Reform Era with the help of collective biography. The paper first assigns stages in Academy members' study paths and adult life course to cultural regions. Then it determines the ratio between these cultural regions, the power of their academic representation, as well as the persons' movement among cultural regions, and the scale and intensity of their mobility.

The investigation is facilitated by mechanisms that the Hungarian Academy of Sciences operated in the Reform Era. These mechanisms aimed at balancing various intersections of belonging, and thus strove for representation in both denominational and geographical terms. Moreover, in the spirit of national development, the Academy's aims of supporting language and arts and managing adult educations were just as pronounced as its scientific objectives. Hence, it is possible to draw conclusions not only about the academic elite but also about the composition of the entire intellectual elite of 19th century Hungary. The term "cultural region" used in the study may in fact be regarded as an extension to the "denominational-cultural clusters" known from ecclesiastical social history and as a bifurcation suitable for portraying spatial divisions.

In the Reform Era, 28\% of members of the Hungarian Academy of Sciences belonged to the Calvinist and $12 \%$ to the Lutheran Church. This means that both denominations were overrepresented in comparison to their importance in the entire population, but the rate of this overrepresentation shows characteristic differences - in fact, the two leading Protestant denominations differ markedly in several respects. In the case of Calvinists, the study demonstrates the outstanding power - and considerable isolation - of Debrecen as its intellectual centre. The Calvinist cultural region in Transylvania delegated members of the Academy in similar numbers as Debrecen; however, its leading cultural figures were linked not only to Kolozsvár (Cluj) but, in part, to Nagyenyed (Aiud) and Marosvásárhely (Târgu Mureș) as well. Decentralization may likewise be detected in other Calvinist cultural regions. However, decentralization is even more pronounced within the Lutheran cultural elite, as exemplified by the visible "ailment" of their strongest traditional centre of education, Pozsony (Bratislava).

Despite the great proportion of Calvinists in the southern part of Transdanubia, half of the Great Hungarian Plain and the northern area of the Transtisza region, these regions did not have a school town, an intellectual centre that could have educated "regional" members of the Academy. This highlights the special role of Debrecen. In contrast, a different strategy may be seen in the case of Lutherans, who had widespread involvement not only in Northern Hungary but were also active in building academic contacts in the south of the Great Hungarian Plain.

Investigating the mobility of members of the Hungarian Academy of Sciences in the Reform Era may provide new arguments for the independence (and isolation) of Debrecen and Transylvania and present convincing numbers that support the growing pull of Pest. 


\section{Bevezetés}

A történeti földrajz szempontrendszerét és módszereit néhány egyéb történeti aldiszciplína régóta szervesen beépítette kutatási gyakorlatába. Ennek megfelelően hazánk térbeli tagolódásának történeti dimenzióit illetően részletgazdag, ugyanakkor az ország vagy a Kárpát-medence egészére átfogóan is érvényes nagy jelentőségű munkákkal rendelkezünk például a néprajz (Kósa, Filep 1978), a gazdaságtörténeti ihletésű várostörténet (Bácskai, Nagy 1984; Beluszky, Győri 2005), vagy épp az agrártörténet (Boros 1999) és a politikatörténet (Pap 2020) bizonyos szegmenseiben. Elvileg az oktatás- és művelődéstörténet is rendelkezhetne ilyen megközelítésű, összefoglaló igényü munkával, hiszen legalábbis a 19. század közepétől a területi tagolódást érintő kérdések megválaszolásához szükséges nagy statisztikai adatsorok rendelkezésre állnak (Nagy 2008). Sőt, mivel általában az egyes iskolavárosok, szellemi centrumok vonzáskörzete, beiskolázási övezete a korábbi évszázadokra vonatkozóan is élénk kutatói érdeklődés tárgya, elvileg régebbi korok viszonyait is eredményesen lehetne vizsgálni (Sasfi 2013, 179-260.). Talán a neveléstörténet és az oktatást rendszeresen vizsgáló társadalomtörténet és egyháztörténet határmezsgyéjén való billegés okán, egyelőre országos léptékü vállalások csak szórványosan születtek ezen a területen.

Tanulmányom részint erre a hiányosságra, részint a témához kapcsolódó, adott esetben kifejezetten szük keresztmetszetű vizsgálatokban rejlő lehetőségekre kívánja felhívni a figyelmet. Az alábbiakban a Magyar Tudós Társaság reformkorban megválasztott tagjai közül a protestánsokra fókuszálok, s az ő tanulmányaik és életpályájuk állomásainak földrajzi elhelyezkedéséből vonok le következtetéseket. Azt feltételezem, hogy a korabeli protestáns szellemi csúcselit összetételének elemzésével hazánk kultúrájának és társadalmának egy igen markáns szegmensét vehetjük górcső alá a térbeli rétegződés szempontjainak segítségével.

\section{A reformkori Akadémia mint vizsgálati terep}

A reformkor egyik legnagyobb hatású kulturális vívmánya a Magyar Tudós Társaság megalapítása volt, s az 1830-40-es éveket messzemenően meghatározták azok a szellemi törekvések, amelyeket az Akadémia koordinált, illetve amelyek kifejezetten a testület ösztönzésére születtek. Bár az intézmény korai története az egyetlen mértékadó monográfiától eltekintve (Vörös 1975) meglepően kevéssé kutatott téma, az mégis közismert, hogy a társaságra a kezdetektől jellemző volt egy tudatosan alkalmazott egyensúlyozó, a legkülönfélébb irányzatokat, megközelítéseket befogadó szerveződési elv. Ennek köszönhetően nemigen akadt olyan tudományos vagy kulturális újdonság, amelynek a hazai szószólóját ne választották volna taggá - legfeljebb csak az egyes táborok, véleménycsoportok közötti arányok differenciálódtak jellegzetesen, bizonyos meghatározó körök, személyi- 
ségek értékvilágának és érdekeinek függvényében (Ugrai 2020). Ez az ellensúlyozásra, de mégsem egyszerü paritásra, hanem valamiféle arányosságra törekvés a korabeli testület alig túlbecsülhető jellemzője. Ennek a tulajdonságnak a figyelembe vételével, a korabeli szellemi csúcselit kollektív biográfiai elemzésével ugyanis sokrétű vizsgálat lefolytatására nyílik lehetőség.

Az Akadémia további két okból is megfelel a reprezentativitás - nyilván történeti dimenzióban, bizonyos megkötésekkel értelmezhető - feltételeinek. A korábbi kora újkori (itáliai testületek, London, Párizs stb.) vagy felvilágosodás kori akadémiaalapításokkal (pl. Innsbruck, Olmütz, Passau, Salzburg) ellentétben a Magyar Tudós Társaság létrejötte nem köthető egyetlen egyházhoz vagy valamilyen jól körülhatárolható egyéb szervezethez, tudós körhöz. Ezzel szemben a nemzeti kibontakozás zászlóshajójaként hangsúlyozottan törekedett az egész ország szellemi áramlatainak megjelenítésére, egy szervezetben való tömörítésére. A korabeli akadémia esetében ráadásul nem is tudományos, hanem szellemi áramlatok összefogásáról beszélhetünk, hiszen a kibontakozó szaktudományok képviselői mellett hangsúlyosan fogadta tagjai sorába a művészeket, írókat, publicistákat, lapkiadókat és különböző közművelődési kezdeményezések kulcsszereplőit. Ily módon az akadémia első korszakának vizsgálata nem pusztán tudományszociológiai, hanem sokkal szélesebb körű művelődéstörténeti következtetések levonását ígéri.

Mindezek mellett a reformkori Pest még távolról sem számított a 19. század végihez hasonló, jelentős iskolavárosnak. Bár az ország egyetlen egyeteme kétségtelenül fontos vonzerőt jelentett, s a nagy múltú piarista gimnázium is sokak szellemi töltekezését szolgálta, a reformkorban pályájuk csúcsára ért szakemberek esetében a Pesthez való közelség vagy a pesti származás, az ottani tanulmányok lényegesen kisebb szerepet játszottak, mint a későbbiekben (Keszei 2018). Ily módon a reformkori Tudós Társaság tagjainak a körében még nem alulreprezentáltak a vidéken született, s a vidéki szellemi centrumok egyikében-másikában tanult tudósok, művészek.

A művészeti és a nemzeti kultúra ápolását szem előtt tartó feladatok halványulásával, a tudományos kutatások intézményesülésének megerősödésével, valamint Pest, majd Budapest szerepének kiemelkedésével a későbbi korszakokban az Akadémia ugyanilyen vizsgálata már inkább „csak” tudománytörténeti és tudománypolitikai összefüggésekkel kecsegtet, semmint a szellemi csúcselit általános tagolódásának megismerésével.

\section{Az Akadémia reformkori tagsága - alapvető számadatok}

A reformkor hajnalán alapított akadémia, akkor még Magyar Tudós Társaság néven 1830-tól választott a soraiba tagokat. A következő szük két évtizedben 273 tudós és művész, illetve az akadémia ügyei iránt elkötelezett férfi került be a 
szervezetbe (Fekete 1975). Közülük 37 főt igazgató tagként választottak meg. Ők döntően politikai-társadalmi súlyuknak köszönhetően kerültek az MTT közelébe, $\mathrm{s}$ tudományos vagy művészeti tevékenységet jellemzően nem végeztek. ${ }^{1}$ Ezúttal őket nem tekintjük az alapsokaság részének, mivel neveltetésük, iskoláztatásuk és az akadémiai mozgalomban való szerepvállalásuk egyaránt annyira eltér a többiekétől, hogy az alábbi elemzési logikába nagyon nehezen lennének beilleszthetők. Ily módon tehát 236 főről állítható, hogy a reformkori Akadémia testületébe beválasztották, s tudósként vagy művészként (is) számoltak vele. Ebbe a 236 fös csoportba beleszámítottuk azokat, akiket már valamilyen státuszt elnyerve, utóbb választottak igazgató taggá - ilyen volt Schedius Lajos és Fáy András. Ugyanakkor az egyszerüsítés kedvéért e 236 fős csoportba nem tartoznak azok, akik eredetileg igazgató tagok voltak, majd azután kaptak tiszteleti tag státuszt is - ilyen a vizsgált korszakban öt esetben, gróf Dessewffy József, gróf Károlyi György, báró Mednyánszky Alajos, gróf Széchenyi István és gróf Teleki József személyével történt.

A leggyakoribb bebocsáttatási forma a levelező tagság volt, a tagok több mint háromnegyede, 185 fö jutott ehhez az elismeréshez. Rendes tagként huszonöten kerültek az Akadémiára, három kivétellel mindannyian az alapító testület tagjai voltak. Tiszteleti tagként 26 fót vettek fel. A 185 levelező tag közül 52 föt emeltek később rendes, 28 főt pedig tiszteleti taggá. (E két utóbbi halmaz között van némi átfedés, hiszen hatan levelező tagból előbb rendes, majd pedig tiszteleti taggá is váltak.) Két reformkorban beválasztott tagból, Eötvös Józsefből és Trefort Ágostonból lett később, jóval a reformkor után az Akadémia elnöke.

Az Akadémia hat osztálya közül a legtöbben az intézmény eredeti kiemelt céljának, a magyar nyelvű irodalom és kultúra megteremtésének megfelelően az I. osztályba kerültek: ebbe, azaz a nyelvi-széptudományi osztályba a tagok 23\%-a (55 fö) lépett be, míg a legkisebb a II. és IV., azaz a philosophiai és a mathematikai osztályba 22-22 fö (9-9\%). Az I. osztály elég nagy létszámfölényben volt, hisz a második legtöbb tagot fogadó történetírási osztály (III. osztály) is csupán 38 fösre duzzadt (16\%) 1848-ig. Igaz, az I. osztály ezt a népes tábort döntően az alakuló testületnek köszönheti, az akkor kiválasztott 22 fö közül nyolcan tartoztak ide. A nyelvészek és szépírók kezdeti, egyharmadot meghaladó részesedése a következő szűk két évtizedben, tehát viszonylag gyorsan $23 \%$ alá csökkent.

A Magyar Tudós Társaság tagjainak több mint a fele római katolikus vallású volt: egyelőre ezt 124 főről tudjuk biztosan. Egy-két eset kérdésesnek tekinthető, illetve a besorolás helyenként gondot okozhat. Így például egy akadémikusról tudjuk, hogy élete során tért át a katolikusról protestáns hitre, illetve fordított irányban is egy katolizálásról tudunk. Ugyanakkor tíz tudós vagy művész felekezeti hovatartozásáról egyelőre nincs kellő ismeretünk, vallásukat nem tudjuk bizonyosan megállapítani. Mindenesetre a római katolikusok 52\%-os jelenléte masszív, abszolút többséget jelent a tagságban. Mellettük kiemelkedő a reformátusok jelenléte: 67 före tesszük jelenleg a reformátusok halmazát - bár itt nyolc valamennyire kérdéses eset is előfordul. (Ez a nyolc fö szinte bizonyosan protes- 
táns volt, de hogy a református vagy evangélikus felekezethez tartoztak-e, azt további kutatások pontosítják majd.) Ez a reformátusok $28 \%$-os jelenlétét jelenti a tagság egészében, ami pedig az országos felekezeti viszonyok tükrében 1,7-szeres felülreprezentáltságot mutat. Huszonnyolc evangélikus tudós vagy művész került az akadémia tagságába, ez a 12\%-os arány szintén felülreprezentáltságot mutat, viszont jóval szerényebbet (1,1-szerest), mint a reformátusok esetében. ${ }^{2}$ (Fontos megjegyeznünk, hogy az evangélikusok reformkori akadémiai reprezentáltsága lényegesen alacsonyabb, mint amit az alfabetizációs kutatások, vagy épp a polgári korszakra vonatkozó elitkutatások alapján feltételezhetnénk. Ezt elsősorban az magyarázhatja, hogy a reformkori akadémia igen erősen kötődött a magyar nyelv és kultúra ápolásához, s ez hátráltatta az evangélikusok német nyelvű szellemi vezetőinek megválasztását.) A reformkori tudós társaságnak a reformátusok és az evangélikusok mellett négy unitárius, két görög katolikus és egy zsidó vallású tagja volt.

A protestáns tagok száma így összesen 99 volt. Az osztályok közötti eloszlásuk hasonló arányokat követett, mint a tagság egészéé, kisebb arányeltolódások ugyan kimutathatók, de ezeket akár a kis elemszám miatt egy-két tudós megválasztása, vagy a megválasztás elmaradása is okozhatta.

\section{Módszertani kitérő: a felekezeti kultúrrégiók és az elnevezésük körüli dilemmák}

A reformkori protestáns akadémikusok földrajzi hovatartozásának meghatározásánál beleütközünk a kultúrrégió problémájába. A besorolásnál ugyanis tekintetbe kell vennünk egyfelől az illető születésének, korai neveltetésének, másfelől tanulmányi pályájának, harmadrészt hivatali állomásainak földrajzi helyeit. Ha ezeket mind a 99 személy esetében egyesével kezdjük helyszínenként, településenként lajstromozni, akkor egy olyan bonyolult, sokváltozós adatbázis alakul ki, aminél fennáll a veszélye annak, hogy alapos elemzést követően sem kínál különösebben fajsúlyos tanulságokat, összefüggéseket. Így a személyes életút egyes településekhez kötődő főbb állomásait érdemesnek tűnik nagyobb egységekbe sorolni, s a továbbiakban ezeknek a térbeli kulturális egységeknek az akadémiai reprezentációját, ezek - egymáshoz is viszonyított - arányait vizsgálni, illetve a tudósok földrajzi mobilitásának jellemzőit is ezekhez az egységekhez kötni.

Ezeket a kulturális és felekezeti alapon összetartozó térbeli egységeket felekezeti jelzővel illetett, azaz esetünkben református vagy evangélikus kultúrrégiónak nevezzük. A magyar egyháztörténeti szakirodalomban kevéssé ismert, nem is pontosan definiált kifejezést nagyon hasonló értelemben használja legújabban Hegyi Ádám (Hegyi 2020a, 87-88.). Mindkettőnk fogalomválasztására nagy hatással volt Kovács I. Gábor felekezeti-művelődési alakzatról szóló tézise, amelynek lényege, hogy ugyanazon felekezethez tartozás is regionálisan eltérő műveltségi 
és kulturális magatartásmintázat mentén írható le, az adott térség sajátos társadalmi, gazdasági, vallási stb. viszonyainak függvényében. Kovács ennek kapcsán óvatosan, egy-két helyen szintén használja a kultúrrégió kifejezést (Kovács 2020). Az ugyanazon földrajzi térhez tartozás korábban kevéssé felismert nagyságú szervező ero, amely adott esetben a nyelvi-etnikai különbségeket is felülírja (Hegyi 2020b).

Feltételezzük tehát, hogy léteztek egymástól jól elkülönülő felekezeti kultúrrégiók. Ezek a valóságban a legtöbb helyen persze multikonfesszionális települések sokaságából álltak, ezzel együtt, amikor felekezeti kultúrrégióról beszélünk, akkor szükségszerüen csak az adott földrajzi térség vizsgált felekezetéhez tartozó közösségeket (és lelkeket) vesszük közvetlenül számításba. Persze az interkonfesszionális kölcsönhatások jelentőségét nem tagadjuk, de a modellalkotás e fázisában kénytelenek vagyunk zárójelbe tenni. Ebből a felfogásból az is következik, hogy az ország egy adott tájegysége egyszerre több felekezeti kultúrrégió része is volt, amennyiben az adott tájegységen több felekezet élt egymással, egymás mellett.

Eredeti feltevésünk szerint az érintett reformkori akadémikusok körében jellemző, domináns földrajzi mobilitási irány függvényében megkülönböztethetünk megtartó, kibocsátó és vonzó kultúrrégiókat. A finomabb distinkciók hangsúlyozása érdekében ugyanakkor adott esetben ezen alapkategóriák párosításával további (al)kategóriák alkalmazására is lehetőségünk nyílik. Megtartó kultúrrégiónak azt tekintjük, amelyik kinevelte és aztán nagyrészt a saját térségében, annak intézményrendszerében foglalkoztatni is tudta az akadémiáig eljutó tudósokat, művészeket. Ezzel szemben a kibocsátó kultúrrégió csupán a kinevelésben jeleskedett, pontosabban feltételezhetően a kinevelést is csak egy pontig tudta hatékonyan ellátni, és ily módon az adott térségből, kulturálisan értelmezhetö közösségből származó kiemelkedő tehetségű személyek egzisztenciáját, illetve társadalmi érvényesülését tartósan már nem tudta garantálni. A korabeli - mai szóval élve - „agyelszívás” másik pólusán pedig azok a vonzó kultúrrégiók álltak, amelyek aránylag nagymértékben más térségekből átcsábított tudósokkal, művészekkel, közművelődési szervezőkkel erősödtek.

Még mielőtt a protestáns akadémikusok kultúrrégiók közötti mozgását alaposan szemügyre vennénk, érdemes a kultúrrégiók konkrét elnevezését megfontolni. Kínálja magát a lehetőség, hogy a korabeli református és evangélikus egyházkerületi elnevezéseket (tiszántúli, tiszáninneni stb.) alkalmazzuk. Ez azonban több szempontból is megkérdőjelezhető megoldás: egyfelől az egyházkerület mégiscsak egy egyházigazgatási egység, s ily módon funkcionális kultúrrégió. Ezzel szemben a nevelkedés, szellemi töltekezés, illetve a felnőtt korban a szellemi hatásgyakorlás az egyházigazgatási egységek határaitól eltérő (annál akár nagyobb, akár szűkebb) mezőben érvényesült. Másfelől az egyházkerületi elnevezések automatikusan szúkítik is a fókuszt: ezekkel az elnevezésekkel az adott felekezet belső egyháztörténetére koncentrálunk, s mellékes körülménnyé teszik azt, hogy az egyházkerületek (esetleg egyházmegyék) legtöbb közös határszaka- 
sza kulturális értelemben, az érintett iskolavárosok és szellemi centrumok tekintetében egyfajta ütközőzóna, közösen használt határmezsgye volt. Ily módon az egyházkerületi alapú besorolás épp ezeket a finom mozgásokat, eltéréseket tenné nehezen megismerhetővé.

Kérdés ugyanakkor, hogy mivel lehet helyettesíteni ezt az elnevezést: egyáltalán lehet-e, érdemes-e kiváltani oly módon, hogy azzal ne okozzunk további (esetleg még nagyobb) zavarokat. Lehetőségként adódik, hogy az egységet az általunk feltételezett perceptuális kultúrrégió legfóbb iskolaközpontjához soroljuk. Ez mindenképpen megfontolandó megoldásnak tűnik. Lényegében ezt a megoldást alkalmazta a már említett Kovács I. Gábor, amikor a "Sárospatak erőterében” címet adta a tiszáninneni származású református egyetemi tanárokat összegyüjtő adattári kötetének (Kovács 2016). Ennek a megoldásnak az alapfeltétele mindenképpen az lenne, hogy az adott iskolaközpont valóban lefedje a kultúrrégióból induló, vagy ott müködő akadémikusok kultúrrégióhoz tartozását.

Ez a debreceni/tiszántúli reformátusok esetében minden esetben érvényesül is: mindenki tanult, illetve a kultúrrégióban felnőtt korukban tartózkodók közül csaknem mindenki tanított is a debreceni kollégiumban. (Két kivétel azért akad: az Akadémia tagja volt Kiss Bálint egyházi író, aki debreceni tanulmányai után Szentes lelkésze volt három évtizeden át. Kuthy Lajos írót is kivételként említhetjük. Ő szintén debreceni tanulmányai után bihari vármegyei tisztségeket viselt.) Ennek megfelelően a Debreceni Református Kollégium és a Tiszántúli Református Egyházkerület reformkori akadémiai reprezentációja csaknem teljes mértékben fedi egymást - ez jól mutatja a debreceni kollégium egészen kiemelkedő regionális szellemi túlsúlyát.

Ha nem is teljes, de igen nagymértékű ez az átfedés a tiszáninneni egyházkerület és a sárospataki kollégium között is. A tiszáninneni közösségből az akadémiára eljutottak közül Ferenczy István kivételével mindenki tanult Sárospatakon: a szobrász Ferenczy Rimaszombatban született, s élete utolsó évtizedét is ott töltötte, de közötte főként Budán élt, illetve Budán, Bécsben és Rómában tanult. A sárospataki kultúrrégió abban mutat a debrecenitől eltérő kulturális mintázatot, hogy a kultúrrégióban maradó, illetve visszalépő akadémikusok nem mindegyikét vonzotta magához a sárospataki kollégium. Szemben a debreceni helyzettel, volt, aki a sárospataki kollégiumtól független egzisztencia birtokában képviselte a tiszáninneni közösséget az Akadémián: Balásházy János Zemplén vármegyei tisztséget viselt, Kazinczy Ferenc széphalmi tartózkodása közismert, az orvos Kováts Mihály Mezőcsáton telepedett le, Ragályi Tamás pedig Borsod vármegye reformkori követe volt. Jászay Pál nyugalmas évei érdekében költözött vissza Abaújszántóra, míg a már említett Ferenczy István ugyanilyen megfontolásból tért haza Rimaszombatba. A sárospataki kollégium tehát a debrecenihez képest jóval kevésbé forrt össze a tiszáninneni református akadémikus szellemi elittel: a régióban maradó vagy oda visszalépő akadémikusok közül csak négyen tanítottak a pataki kollégiumban, hatan viszont nem. És legyünk figyelmesek arra, hogy a le- 
telepedés, esetleg a polgári foglalkozás helyszíneként Patakkal szembeni alternatívául szolgáló települések a tiszáninneni egyházkerület tradicionális térségei: Abaúj (Abaújszántó), Borsod (Mezőcsát, Miskolc), Gömör-Kishont (Rimaszombat). Ily módon a „sárospataki kultúrrégió” helyett talán indokoltabbnak tűnik a tiszáninneni református kultúrrégió kifejezés használata.

Másik irányból is kiválóan illusztrálja az elnevezés körüli bizonytalanságokat a Duna-Tisza közén élő reformátusok esete. A körzet egyfelől a Dunamelléki vagy Dunáninneni Református Egyházkerülethez tartozott. (Még az egyházkerület hivatalos elnevezése sem állandó a tágabban vett korszakban.) Ám ez az egyházkerület számottevő dunántúli (Fejér, Tolna, Baranya, illetve egy időben még Somogy megyékhez tartozó) térségeket is magába foglalt, másfelől idetartozott Pest is. Pestet minden szempontból érdemes magában vizsgálni, külön kultúrrégióként (vagy kultúrcentrumként) kezelni. A korabeli református akadémikusok földrajzi hovatartozását vizsgálva pedig azt látjuk, hogy miközben baranyai, Fejér megyei vagy somogyi illetőségű tudósok, művészek vagy nem lettek a Tudós Társaság tagjai, vagy valamelyik másik iskolacentrumhoz gravitáltak, a Kecskemét-Nagykőrös-Kiskunhalas háromszögben, ha nem is nagy számban, de jellemző módon megfordultak életük során akadémikusok. (Sőt az egyébként tiszáninneni származású Gelei József kiskunhalasi éveit megelőzően rövid ideig a térséghez tartozó Jászberényben is szolgált - katolikus iskola tanáraként is.) Ebben a példában azt láthatjuk, hogy a debreceni kultúrrégióval szöges ellentétben nem érvényesült egyetlen iskolaközpont centrális szerepe, miközben a decentrumok együttese így is csupán a hivatalos egyházkerületnek legfeljebb a felére terjedt ki. Ezért ezt dunamelléki-alföldi református kultúrrégiónak neveztük el.

Újabb esetet teremtenek a Dunántúli Református Egyházkerület viszonyai. Egyfelől az egyházkerületnek itt is csak az egyik fele, a Balatontól északra eső területek jelennek meg helyszínként a reformkori akadémikusok életpályájában: somogyi, zalai állomások legfeljebb kivételként említhetők, s jobbára csak átmeneti jelleggel játszottak szerepet az illető szellemi töltekezésében. (Kivételként itt a Debrecenben, majd Sárospatakon tanuló, végül Kaposvárott letelepülő Csorba József orvos említhető.) Az észak-dunántúli reformátusok szellemi elitje azonban nem egy centrumhoz, de nem is több decentrumhoz gravitált - hanem két, egymással nem teljesen egyenrangú, mégis aránylag kiegyensúlyozottan konkuráló iskolaközponthoz. A 13 érintett akadémikus közül kilenc fö Pápán tanult vagy tanított, négy fö pedig Komáromban született, tanult vagy aktív éveiben ott működött. Általában a komáromiak eljutottak néhány esztendő erejéig Pápára is, de például a komáromi születésü Péczely József úgy lett országosan ismert tudós, hogy szülőhelyéről Pápa kihagyásával került Debrecenbe, s ugyanígy, a révkomáromi lelkész fiaként született Tóth Lőrinc jogász, író sem tanult Pápán. A jelenség miatt a térséget pápai-komáromi református kultúrrégiónak hívjuk.

Minden bizonnyal az Erdélyi Egyházkerület megítélése a legnehezebb. Egyfelől az egész erdélyi reformátusság egyházszervezeti fejlődése sok eltérő sajátos- 
ságot mutat a királyi Magyarország területén működő egyházkerületekkel összevetve. Ez mindenképpen az egységes, erdélyi kultúrrégió kifejezés használatát sugallja. Ugyanakkor az erdélyi egyházkerületen belül voltak markáns különbségek, amelyekre egyre több egyháztörténeti, egyházi társadalomtörténeti kutatás hívja fel a figyelmet (Tóth 2015). A reformkori erdélyi akadémikusok iskoláztatásában és pályafutásában is kirajzolódik legalább egy erős határvonal, amelyet nem hagyhatunk említés nélkül. Az összesen 21 erdélyi protestáns (református és unitárius) akadémikus közül heten tanultak Kolozsvárott, heten Nagyenyeden és ketten Marosvásárhelyen. Pályájuk során heten éltek és működtek hosszabban Kolozsvárott, ketten Nagyenyeden és öten Marosvásárhelyen. A Nagyenyedről Marosvásárhelyre irányuló mozgás nem volt ismeretlen - sőt mi több, Bolyai Farkas és Köteles Sámuel személyes életútja egészen kiemelkedő példákkal illusztrálja a mobilitás ezen irányát. De Herepei Károly tanult mindhárom városban, s tanárként müködött Nagyenyeden és Kolozsvárott is. A Teleki-tékát alapító Teleki Domokos neve ugyan összeforrott Marosvásárhellyel, Vásárhely mellett azért ő is tanult Nagyenyeden is. A Kolozsvár és Marosvásárhely közötti mozgások ugyanakkor feltűnően ritkák, ami a két szellemi centrum közötti lényegesebb különbségek meglétére utal. A három város közötti - nem egyenrangú - mozgások, illetve a 21 akadémikus három város közötti „eloszlásának” a szórtsága talán azt indokolja jobban, hogy erdélyi református kultúrrégióról, s azon belül két kultúrvidékről, a nagyenyedi-kolozsvári, valamint marosvásárhelyi kultúrvidékekról beszéljünk.

Hasonlóan érdekes különbségek mutathatók ki az evangélikus akadémikusok életét vizsgálva. Pozsony esetében teljesen homogén módon érvényesült a helyi evangélikus líceum vonzó hatása: aki a lutheránus reformkori akadémikusok közül kapcsolatba került Pozsonnyal, kivétel nélkül ennek az intézménynek a deákja, netán tanára volt. Itt tehát a földrajzi név kiválasztásával nincs sok gondunk. Dilemmát okoz viszont az, hogy beszélhetünk-e egyáltalán a pozsonyi érdekeltségű evangélikusok esetében kultúrrégióról: meglehetősen gyakori ugyanis, hogy csupán a jogi stúdiumok erejéig tanultak ott a később magasra jutott tudósok - ily módon Pozsony szerepe egyfajta kultúrsziget-jelenségként is értelmezhető. E kifejezés alatt azt értjük, amikor az illető, adott esetben egészen távolról is, valamilyen fontos, máshol nehezen pótolható stúdium érdekében keresi fel az érintett iskolát és várost, de a stúdium elvégzését követően, akár már egy-két esztendő elmúltával is távozik. Ilyenkor az érintett személy a város és a régió kulturális szövetébe szükségszerűen csak szórványosan integrálódik, és általában nem feltétlenül kerül a felkeresett várost övező kultúrrégióval intenzív szellemi kölcsönhatásba.

Pozsonnyal szemben Sopron sokkal összetettebb szerepet játszott a protestáns szellemi csúcselit regionális kötődésű tagjainak körében. Összesen tizenhárman tanultak a soproni gimnáziumban és líceumban, s közülük többen is letelepedtek a környéken. Berzsenyi Dániel, Edvi Illés Pál, Horváth Zsigmond és Kis János is a Nyugat-Dunántúlon élte le élete nagy részét - előbbi a birtokain gaz- 
dálkodott, az utóbbi három pedig evangélikus lelkészként szolgált Győr, Sopron, Vas, Zala megyei gyülekezetekben. Emiatt a Sopron centrumhoz kötődő térséget talán szerencsésebb nyugat-dunántúli evangélikus kultúrrégiónak nevezni.

A dél-alföldi, Békés megyei evangélikus akadémikusok Mezőberényben, illetve az ottani iskola elköltözése után Szarvason tanultak vagy tanítottak. Kizárólag az iskola biztosította a földrajzi térséghez való - egyébként kisszámú, s gyenge, átmeneti - kötődéseket. Ezért szarvasi-mezőberényi evangélikus kultúrrégióként tartjuk számon ezt a kört.

Távolról sem egyértelmű a Tiszai Evangélikus Egyházkerülethez tartozó településekről származó vagy ott tanuló akadémikusok kulturális földrajzi alapú besorolása. Az egyházkerület, roppant méretei miatt, nem feltétlenül alkalmas az annál jóval szűkebb földrajzi térre koncentrálódó szellemi hátország elnevezésére. A 15 érintett reformkori akadémikus közül nyolc fö kötődött a Szepességhez, az ottani iskolaközpontokhoz (Késmárk, Lőcse). A sárosi Eperjeshez szintén nyolcan, gömöri helyszínekhez (Csetnek, Rozsnyó, Sajógömör) öten, Besztercebányához és Selmechez öten, Losonchoz négyen, Miskolchoz pedig szintén négyen kötődtek. Egy-egy személy pályájában jelent meg Gyöngyös, illetve Kassa aránylag markánsan. Egyértelmü tehát, hogy egy nagyon decentralizált, sokszínü szellemi térkép festhető fel, ami azonban egyetlen esetben sem nyúlt át a Tiszántúlra, s a legtöbb esetben a Miskolc-Rozsnyó-Losonc-Selmec-BesztercebányaLőcse-Késmárk-Eperjes-Kassa-Miskolc körön belül koncentrálódott. Ennek megfelelően ezt észak-magyarországi evangélikus kultúrrégiónak nevezzük.

Ugyanakkor a reformátusok körében egy ideig elterjedt szepességi nyelvtanulás ugyanennek a térségnek egy kisebb körére koncentrálódott, s 10 esetben a késmárki, lőcsei, selmeci, valamint egy esetben az eperjesi líceumban való egykét éves célzott nyelvtanulást jelentett. Ez lényegileg eltér attól, amikor valaki ennél sokkal hosszabban, több társadalmi kapcsolatot kiépítve, eredetileg a tartós letelepedés esélyével tartózkodik akár tanulmányai, akár felnőtt élete során egyegy helyen. Ráadásul itt jellemzően reformátusok evangélikus környezetben való - ismételjük: átmeneti - tartózkodásáról beszélhetünk. Ezért ezt a jelenséget lényegileg másként értelmezzük, s a szepességi kultúrsziget kifejezéssel illetjük. Ez a kultúrsziget-jelenség a protestáns akadémikusok körében még egy helyen tűnik fel (a már jelzett Pozsony mellett): igaz, csak két esetben, de a keszthelyi Georgicon is ugyanilyen átmeneti, célzott tanulmányi tartózkodásra nyújtott lehetőséget.

\section{Protestáns akadémikusok és kultúrrégióik}

Összesen 97 protestáns tudós vagy művész kultúrrégiókhoz sorolását és kultúrrégiók közötti mozgását tudjuk elvégezni - két személlyel egyelőre inkább nem számolunk, mert az életútjuk részletesebb feltárása további kutatások feladata. ${ }^{3} \mathrm{~A}$ legtöbb akadémikust a debreceni református kultúrrégió bocsátotta ki: a debre- 
ceni kollégium közvetlen vonzáskörzetébe tartozó területről származók és ott nevelkedők száma 20 fó. A második legnagyobb csoportot az erdélyi református kultúrrégió biztosította 19, a harmadikat pedig a tiszáninneni református kultúrrégió 17 fóvel. Az erdélyi halmazhoz sorolt 19 fö közül a nagyenyedi-kolozsvári kultúrvidékhez tizenhárman, a marosvásárhelyihez pedig hatan tartoztak. A protestáns kultúrrégiók további sorrendje így alakult: észak-magyarországi evangélikus kultúrrégió - 14 fó, pápai-komáromi református kultúrrégió - 12 fó, nyugat-dunántúli evangélikus kultúrrégió - kilenc fó, szarvasi-mezőberényi evangélikus kultúrrégió - két fo", dunamelléki-alföldi református kultúrrégió - két fö, pozsonyi evangélikus kultúrrégió - két fö (lásd a Melléklet 1. táblázatát).

Ezek az abszolút számok már önmagukban is izgalmas következtetésekre adnak lehetőséget. A reformátusok belső arányait illetően a legerősebb debreceni kultúrrégió akadémiai jelenléte mindössze 1,16-szor volt nagyobb a tiszáninneninél és 1,6-szor a pápai-komárominál. Emellett pedig szinte teljesen megegyezett az erdélyi és a debreceni kultúrrégió akadémiai jelenlétének nagysága. Ezen a ponton tehát az oktatástörténeti arányokból következtethető különbségeket jelentősen csökkentette az akadémiai rekrutáció volumene: a nagy anyaiskolák közötti különbségeket nem erősítette, hanem ellensúlyozta a földrajzi-kulturális térségek közötti akadémiai olló.

Az evangélikusok esetében épp ellenkező tendenciát látunk érvényesülni: az iskolázás közel egyenlőségen alapuló erőviszonyait jellegzetesen felborítják az akadémiai rekrutáció számai. Az észak-magyarországi evangélikus kultúrrégióból az Akadémiára beválasztottak száma másfélszer nagyobb, mint a nyugat-dunántúli és nagyon sokkal, hétszer több mint a pozsonyi evangélikus iskolaközpont térségéből érkezetteké.

Ha ellenkező előjellel is, de mind a reformátusok, mind az evangélikusok esetében azt látjuk, hogy a szellemi csúcselitbe való bekerülés egyszerü abszolút számai jelentősen felülírják azt a viszonyt, amit eddig az oktatástörténetből, az egyes iskolák diákszámának nagyságából vagy épp az iskolaközpontok tanszékeinek, professzorainak a számából ismertünk (Bajkó 1976; Durovics 2017).

A kultúrrégiónként eddig tárgyalt abszolút számok azonban nem árulnak el eleget az adott térségben élő közösség kulturális megtartó és vonzerejéről. Hiszen csupán arról informál, hogy mely földrajzi térségben születtek és kezdtek tanulni az Akadémiára végül beválasztott tudósok, művészek. Ennél árnyaltabb megközelítésre ad lehetőséget, ha az illetők további mozgását is alaposan szemügyre vesszük (lásd a Melléklet 2. táblázatát). Előbb azt nézzük meg, hogy hányan voltak olyanok, akik az adott kultúrrégiót elhagyták. A kultúrrégióból való kilépésként a tartós letelepedéssel járó elköltözést azonosítjuk. Ennek alapesete a más kultúrrégióban való elhelyezkedés.

Emellett hosszabb mérlegelés után a tanulmányok megkoronázására szolgáló - szükségszerủen pesti - egyetemi évek érdekében történő távozást is a kultúrrégióból való kilépéshez soroljuk. Ennek két oka van. Egyfelől Pest egyre komo- 
lyabb vonzerőt gyakorolt a hosszú távú letelepedésre, s így érvényesült az a mechanizmus, miszerint aki vidékről származva pesti stúdiumok mellett határozott, jó eséllyel nem is tért már később haza. Ebben az esetben tehát nem kultúrszigetjelenségről, hanem egy másik, fejlődő kultúrcentrum vonzó, elszívó hatásáról beszélhetünk.

Másfelől a pesti továbbtanulás, vagy annak hiánya, helyben történő mellőzhetősége fontos adalék a vidéki kultúrrégió oktatási szolgáltatásainak teljességére, illetve teljesnek tekintettségére. Láthatjuk például, hogy a Debreceni Református Kollégiumban teljesített tanulmányokat aránylag gyakran fogadták el - legalábbis helyben - teljes értékünek, s a deákoknak nem kellett Pesten kiegészíteniük ismereteiket. Ezzel szemben a számadatok azt mutatják, hogy a pápai, késmárki, eperjesi, netán sárospataki tanulmányok viszonylag ritkán számítottak akár helyben is teljesnek vagy olyan súlyúnak, amelyek az illetőket aztán az országos szellemi csúcselitbe való kandidálásra is feljogosították volna.

A pesti továbbtanulást tehát az adott vidéki kultúrrégióból való kilépésként értelmezzük, s ha valaki a pesti egyetem után hazaköltözött, akkor azt az adott kultúrrégióba való visszalépésnek tekintjük. Ezt a ki- és visszalépést nem rögzítjük akkor, ha az illető - más magyarországi továbbtanulási helyszín közbeiktatása nélkül - csupán külföldi peregrináción vett részt. Mivel a peregrináció hangsúlyozottan átmeneti, s a nyilvánvaló anyagi nehézségek miatt igencsak szűkre szabott idejü elutazásként értelmezhető (a letelepedés, a külföldön maradás alapvetően csekély esélyével), az akadémiai érvényesülés és a kultúrrégiók közötti földrajzi mobilitás kombinált értelmezésének szempontjából megítélésünk szerint nem tekinthető a kultúrrégióból való kilépésnek.

A debreceni református kultúrrégióból kilépók száma kilenc volt. Az erdélyiből heten, a tiszáninneniből tizenhárman, a pápai-komáromiból pedig tizenegyen léptek ki. Az evangélikus kultúrrégiók közül az észak-magyarországit 11, a nyugat-dunántúlit négy, a pozsonyit és a szarvasi-mezőberényit pedig két-két fó hagyta el. Az utóbbi két evangélikus kultúrrégióban született és nevelkedett mindkét tudós tehát élete során elköltözött a szülőföldjéről. Ez már jelentősen átrendezi az első körben kialakult viszonyokat, de a következő mérlegmegvonás előtt érdemes külön vizsgálni a kultúrrégióba visszatérook számát is. Ők azok a kultúrrégióból kilépők, akik életük későbbi részében visszatértek születésük, eredeti lakhelyük vagy eredeti iskolázásuk színhelyére (illetve annak hátországába). Református oldalon a debreceni kultúrrégiót elhagyó kilenc fö közül hárman, az erdélyi régiót elhagyó hét fö közül szintén hárman, a tiszáninneni kultúrrégiót elhagyó 13 fó közül heten, a pápai-komáromit elhagyó 11 fő közül hárman tértek vissza eredeti kultúrrégiójukba.

Az evangélikus kultúrrégiók közül az észak-magyarországit elhagyó 11 fö közül három tért vissza. A nyugat-dunántúlit elhagyó négy fö közül senki nem költözött aztán később vissza, mint ahogyan sem a pozsonyi, sem a dél-alföldi kilépők között nem találunk visszalépőt. 
A kultúrrégióban nevelkedettek, az onnan kilépők és az oda visszalépők mérlegét megvonva már a debreceni kultúrrégió komolyabb fölényét tapasztaljuk a többi református közösséghez képest: a 20 ott születettből kilenc kilépett, három viszont visszalépett. Így a Tiszántúlon született akadémikus közösség a reformkorban összesen 14 fös volt. ${ }^{4}$ Az erdélyi kultúrrégióban 19-en születtek, heten léptek ki a térségből, hárman viszont visszaléptek, így a helyi származású akadémikus közösség létszáma 15 fös volt. A tiszáninneni közösségben 17-en születtek a későbbi akadémikusok közül - a 12 kilépőből hatan tértek vissza, azaz a közösség létszáma 11 főss volt. A pápai-komáromi közösség 12 fős alaphalmazából tizenegyen távoztak életük során, közülük hárman tértek vissza - így a közösség létszáma csupán négy fö volt. A dunamelléki-alföldi reformátusok két későbbi akadémikus kineveléséhez járultak hozzá - közülük egy végérvényesen távozott, egy pedig maradt a térségben.

Az egyes kultúrrégiók megtartó és kibocsátó kapacitását követően egy újabb szempontot emelünk be a vizsgálatba. Figyeljünk ezúttal a kultúrrégiók vonzerejére, s ennek megfelelően a kultúrrégióba belépókre! Azaz arra, hogy az egyes kultúrrégiókba hányan léptek be azok közül, akik nem ott születtek és eredetileg nem ott nevelkedtek. A debreceni kultúrrégió három, az erdélyi két, a tiszáninneni öt, a pápai-komáromi egy, a dunamelléki-alföldi református kultúrrégió pedig két belépőt vonzott. Közülük azonban a debreceniben és a dunamelléki régióban is csupán egyegy fö telepedett le véglegesen. A tiszáninneni, az erdélyi és a pápai-komáromi kultúrrégióba mindössze átmenetileg érkeztek az akadémiai elitbe eljutó tudósok, ezek a kultúrrégiók a tartós letelepedésükhöz nem bizonyultak eléggé vonzónak. A református kultúrrégiók erősorrendjét, megtartó képességükről alkotott képünket tehát ez a szempont nem befolyásolja jelentősen. Inkább arra hívja fel a figyelmünket, hogy a református egyház egyes nagy vidékei alapvetően egymáshoz képest is zártak voltak, s a térségek közötti közvetlen, a személyek szabad mozgásán alapuló szellemi kölcsönhatás nem becsülhető kiemelkedően nagynak.

A kultúrrégióba belépők vizsgálata egészen más következtetésekre vezet az evangélikusok esetében. Itt azt látjuk, hogy az akadémikusokat kiemelkedő számban kinevelő - de jellemzően nem a térségben tartó - szepesi iskolacentrumok a 19. század első harmadában már nem voltak különösebben vonzóak a nem helyiek szemében. Ennek megfelelően csupán egy belépővel számolhatunk, aki rövid idő után távozott is a kultúrrégióból. (Mindennek minden bizonnyal a fó oka a magyar nyelv és kultúra iránti érdeklődés erősödése, s ily módon a vegyes etnikumú térség fokozatos háttérbe szorulása.) Ezzel szemben a soproni körzet négy, a pozsonyi pedig nem kevesebb, mint 15 későbbi akadémikust fogadott - de egy átmeneti idő után mind a 19 fó el is hagyta a soproni, illetve pozsonyi térséget. Érdekes módon a szarvasi-mezőberényi evangélikus kultúrrégió két későbbi akadémikust is vonzott, akiket ráadásul halálukig meg is tartott.

Ily módon az evangélikusok kulturális kölcsönhatása a reformátusokétól eltérő mintázatot mutat: sokkal nyitottabb, rendszeresebb interakciókkal jellemez- 
hető, amely az egyes vidéki iskolaközpontok intenzívebb felkeresését és elhagyását jelenti. Ugyanakkor az evangélikusok esetében ez a mozgás azt is illusztrálja, hogy mennyire nem volt a többi fölé emelkedő, jellegzetes központja - a korábban ezt a szerepet betöltő Pozsony ugyanis már sem a saját maga által kinevelt két, sem pedig a líceum által bevonzott 15 fó városban (és régiójában) tartásához nem volt eléggé erős.

A kultúrrégióból kilépő, illetve oda csak átmenetileg belépő, majd onnan ismét távozó későbbi akadémikusok további úti célját, letelepedésének a helyét megvizsgálva határozott tendenciákra nem következtethetünk (lásd a Melléklet 2. táblázatát). Nyilván kimutatható Pest elszívó hatása - szinte - minden esetben, de távolról sem azonos mértékben: a legtöbb kiemelkedő gondolkodót a tiszáninneni református közösség veszítette el Pest vonzereje miatt (18 főből 10 Pestre költözött). Hasonló arányban távoztak az új, egyre erősödő fővárosba a szepesi, soproni és pozsonyi evangélikus körzetekből. A többi kultúrrégió esetében, illetve a nevezett kultúrrégiókból a nem Pestre költöző tudósok körében egyéb tendencia nem körvonalazódik. Egyedül a pápai-komáromi református kultúrrégióból Pozsonyba irányuló aránylag nagy belső migráció szembeszökő.

Pest város vonzereje egyébként 45 protestáns reformkori akadémikusra terjedt ki, közülük tizennyolcan tanulmányokat folytattak (nem feltétlenül az egyetemen, hanem például a mérnöki intézetben vagy rajziskolában), hárman jogvagy ügyvédi gyakornoki időt töltöttek ott, míg harmincnégyen pályafutásuk egy részét vagy egészét is Pesten töltötték.

\section{Összegzés}

Tanulmányunkban a reformkori Akadémia protestáns tagjainak földrajzi hovatartozását vizsgáltuk kollektív biográfiai eszközökkel. A tanulmányi pálya és a felnőtt életutak állomásait kultúrrégiókhoz soroltuk. Ezt követően a kultúrrégiók egymáshoz viszonyított arányát, akadémiai reprezentációjuk erejét, illetve a személyek kultúrrégiók közötti mozgását, földrajzi mobilitásuk nagyságát és intenzitását határoztuk meg.

A vizsgálatot az tette lehetővé, hogy a reformkori Akadémia mindenféle metszésvonal mentén egyensúlyozó mechanizmusokat működtetett, s így felekezeti és földrajzi értelemben is egyfajta reprezentativitásra törekedett. A nemzeti kibontakozás jegyében ráadásul nemcsak tudományos, hanem nyelv- és művészetpártoló, művelődésszervező célkitűzései is hangsúlyosak voltak. Ily módon nemcsak a tudományos, hanem a tágabban vett szellemi elit egészének összetételére nézve is érvényes következtetéseket vonhatunk le. A tanulmányban alkalmazott felekezeti színezetű (protestáns) kultúrrégió kifejezés pedig az egyházi társadalomtörténetben egyre inkább meggyökeresedő „felekezeti-művelődési alakzat” kiterjesztésének, a térbeli tagolódás megjelenítésére alkalmas elágazásának tekinthető. 
A reformkorban a Magyar Tudós Társaság tagjává választottak 28\%-a református, 12\%-a pedig evangélikus volt. Mindkét felekezet felülreprezentált volt tehát az összlakosságban elfoglalt súlyukhoz képest, de a felülreprezentáltság mértéke jellegzetes különbséget mutat: az evangélikusok esetében ez „csak” 30-33, a reformátusok esetében viszont 75\%-os volt. A reformátusok esetében ezzel a módszerrel is kimutatható Debrecen mint szellemi központ ereje - és egyúttal meglehetősen erőteljes zártsága. Debrecenhez hasonló arányban delegált akadémikusokat az erdélyi református kultúrrégió, amely azonban a kulturális élet vezéreit nem kizárólag Kolozsvárhoz, hanem részben Nagyenyedhez és Marosvásárhelyhez is kötötte. A decentralizáció jegyei a többi református kultúrrégióban is kimutathatóak.

Debrecen kulturális kiemelkedettsége még sajátosabb jelenséggé válik, ha az evangélikus kulturális csúcselit térbeli tagolódására is vetünk egy pillantást. A lutheránusok körében ugyanis még inkább jellemző a decentralizáltság - ennek érzékletes példáját a hagyományos, legerősebb iskolaközpont, Pozsony látványos „gyengélkedése" szolgáltatja.

A református kultúrrégiók esetében szembeszökő, hogy hiába éltek jelentős arányban kálvinisták a Dél-Dunántúlon, az Alföld felén, az Észak-Tiszántúlon, nem rendelkeztek olyan iskolavárossal, szellemi központtal, amely alkalmas lett volna legalább egy-két akadémikus kinevelésére. Mindez természetesen megint csak Debrecen egészen különleges szerepére világít rá. Ehhez képest is másféle stratégia bontakozik ki az evangélikusok részéről, akiknek nemcsak az akadémikusok által lefedett észak-magyarországi érdekeltsége volt viszonylag kiterjedt, de a Dél-Alföldön is rendelkeztek akadémiai kapcsolatokkal.

A reformkori akadémikusok mobilitását vizsgálva Debrecen és Erdély önállóságához (zártságához) nyertünk újabb érveket, emellett pedig Pest immár egyre erőteljesebb vonzó hatása is alátámasztható meggyőző számokkal.

\section{Jegyzetek}

1 E 37 igazgató tag egészen különleges szerepet töltött be a korabeli társadalomban és kultúrában, ezért velük egy külön tanulmányban foglalkozunk majd.

2 1790-ben Magyarország, Erdély és a Partium népességének (Szlavónia, Horvátország és a Határőrvidék nélkül) 46,7\%-a római katolikus, 7,5\%-a görög katolikus, 17,6 \%-a görögkeleti vagy ortodox, 10,2\%-a evangélikus és 16,4\%-a református volt (Balogh, Gergely 1996, 149.).

3 A Bián született Tanárky Sándor katonaként gyakran változtatta tartózkodási helyét. A drámaírói érdemeiért az I. osztályba való beválasztással 1831-ben elismert Jakab Istvánról pedig ugyan tudjuk, hogy református családba született a borsodi Mezőkeresztesen, de apja a nagyváradi katolikus püspökség gazdatisztje volt, s ezért ő maga is Nagyváradon járt katolikus iskolába, majd a pesti egyetemre.

4 Természetesen nem feltétlenül éltek egy időben mind a tizennégyen, de ez most mellékes is, hisz nem arra vagyunk kíváncsiak, hogy hány helyi akadémikus gyülhetett össze egy debreceni teremben, hanem arra, hogy hány fő jutott el az adott térségből a reformkor során a szellemi csúcselitbe. 


\section{Köszönetnyilvánítás}

A tanulmány a Magyar Tudományos Akadémia Bolyai János Posztdoktori Ösztöndíjának támogatásával készült.

\section{Irodalom}

Bácskai V., Nagy L. (1984): Piackörzetek, piacközpontok és városok Magyarországon 1828-ban. Akadémiai Kiadó, Budapest

Bajkó M. (1976): Kollégiumi iskolakultúránk a felvilágosodás idején és a reformkorban. Akadémiai Kiadó, Budapest

Balogh M., Gergely J. (1996): Egyházak az újkori Magyarországon 1790-1992. História, MTA Történettudományi Intézete, Budapest

Beluszky P., Győri R. (2005): Magyar városhálózat a 20. század elején. Dialóg Campus, Budapest

Boros L. (1999): A Kárpát-medence szólő- és borgazdaságának történeti földrajza. Nyíregyházi Főiskola Földrajz Tanszéke, Nyíregyháza

Durovics A. (2017): Utak és lehetőségek. Pozsony és Sopron líceumának összehasonlító elemzése. Gerundium, 1., 220-238.

Fekete G. (1975): A Magyar Tudományos Akadémia tagjai 1825-1973. MTA Könyvtára, Budapest

Hegyi Á. (2020a): Hogyan lesz magánkönyvtárból közösségi könyvtár? Példák két délvidéki református egyházmegye lelkészi könyvtáraira a 18-19. század fordulóján. In: Dóbék Á. (szerk.): Könyvek magántulajdonban (1770-1820). Reciti Kiadó, Budapest, 87-98.

Hegyi Á. (2020b): Regionális vallási identitástudat kialakulása a Bánátban élő német és magyar reformátusok között a 18-19. század fordulóján. In: Kolumbán V. J. (szerk.): Egyház, iskola, művelődés. Egyháztörténeti tanulmányok. Kolozsvári Protestáns Teológiai Intézet, Kolozsvár, 213-223.

Keszei A. (2018): A középfokú oktatás felekezeti változatai és társadalmi háttere a 19. század első felében Pesten. Korall, Budapest

Kósa L., Filep A. (1978): A magyar nép táji-történeti tagolódása. Akadémiai Kiadó, Budapest

Kovács I. G. (2016): Sárospatak erőterében. A tiszáninneni származású református egyetemi tanárok életrajzi adattára és életútleírása. Magyarországi egyetemi tanárok életrajzi adattára 1848-1944 III. ELTE, Eötvös Kiadó, Budapest

Kovács I. G. (2020): A magyarországi tudáselitek (1848-1944) és a felekezeti - művelődési alakzatok. In: Kiss R., Lányi G. (szerk.) HIT 2018. Hagyomány, identitás, történelem. L' Harmattan Kiadó, Budapest, 135-150.

Nagy P. T. (2008): Az iskolai elitek és az iskolázott elitek kutatása. Új Pedagógiai Szemle, 4., 80-95.

Pap J. (2020): A dualizmus kori parlamentarizmus térbelisége. Képviselók és förendek a dualizmus kori Magyarországon. Parlamentarizmustörténeti tanulmányok I. Líceum, Eger, 9-32.

Sasfi Cs. (2013): Gimnazisták és társadalom Magyarországon a 19. század első felében. Korall, Budapest

Tóth L. (2015): Református egyháztörténeti kutatások Erdélyben 2002-2013 között. In: Péntek J., Salat L., Szikszai M. (szerk.): Magyar tudományosság Romániában 2002-2013 között. 1. kötet. Ábel Kiadó, Kolozsvár, 201-222.

Ugrai J. (2020): Pedagógiai gondolkodók az Akadémián a reformkorban. In: Garai I., Kempf K., Vincze B. (szerk.): Mestermunka. A neveléstudomány aktuális diskurzusai. ELTE PPK, L'Harmattan, Budapest, 85-97.

Vörös A. (szerk.) (1975): A Magyar Tudományos Akadémia másfél évszázada 1825-1975. Akadémiai Kiadó, Budapest 


\section{Melléklet}

1.táblázat: Reformkori akadémikusok földrajzi hovatartozása és mobilitása Geographical affiliation and mobility of reform-era academics

$\begin{array}{ccccc}\text { Kulturregioban } & \text { Kulturregiobol } & \text { Kulturregiobol } & \text { Kulturregioba } & \text { Kulturregıoba } \\ \text { nevelkedett } & \text { kilépőreform- } & \text { kilépó, majd } & \text { belépóreform- } & \text { belépó, majd } \\ \text { reformkori } & \text { koriakadémi- } & \text { visszatérö } & \text { kori akadémi- } & \text { onnan távozó } \\ \text { akadémikusok } & \text { kusok } & \begin{array}{c}\text { reformkori } \\ \text { akadémikusok }\end{array} & \text { kusok } & \begin{array}{c}\text { reformkori } \\ \text { akadémikusok }\end{array} \\ & & & \end{array}$

\begin{tabular}{lccccc}
\hline $\begin{array}{l}\text { Debreceni } \\
\text { református }\end{array}$ & 20 & 9 & 3 & 3 & 2 \\
$\begin{array}{l}\text { Erdélyi református } \\
\begin{array}{l}\text { Tiszáninneni } \\
\text { református }\end{array}\end{array}$ & 19 & 7 & 3 & 2 & 2 \\
$\begin{array}{l}\text { Pápai - komáromi } \\
\text { református }\end{array}$ & 12 & 13 & 7 & 5 & 5 \\
$\begin{array}{l}\text { Dunamelléki - } \\
\text { alföldi református }\end{array}$ & 2 & 11 & 3 & 1 & 1 \\
$\begin{array}{l}\text { Észak-magyar- } \\
\text { országi evangélikus }\end{array}$ & 14 & 1 & 0 & 2 & 1 \\
$\begin{array}{l}\text { Pozsonyi } \\
\text { evangélikus }\end{array}$ & 2 & 11 & 3 & 1 & 1 \\
$\begin{array}{l}\text { Nyugat-dunántúli } \\
\text { evangélikus }\end{array}$ & 9 & 4 & 0 & 15 & 15 \\
$\begin{array}{l}\text { Szarvasi - mezőbe- } \\
\text { rényi evangélikus }\end{array}$ & 2 & 2 & 0 & 4 & 0 \\
\hline
\end{tabular}

Forrás: a szerző saját szerkesztése 
2. táblázat: Kultúrrégióból kilépő reformkori akadémikusok távozásának földrajzi céljai Geographical destinations of academics leaving the cultural region Kultúrrégióból kilépö későbbi Kilépés földrajzi célterületei reformkori akadémikusok száma

\begin{tabular}{|c|c|c|}
\hline Debreceni református & $9+2$ & $\begin{array}{l}\text { Pest: 4; Pozsony: 3; Szepesség: } \\
\text { 2; Pápa, Sárospatak: 1-1 }\end{array}$ \\
\hline Erdélyi református & $7+2$ & $\begin{array}{l}\text { Pest: } 2 \\
\text { Bécs, Brassó katolikus iskola, } \\
\text { Bukarest, Kolozsvár katolikus } \\
\text { iskola, világutazás: 1-1 }\end{array}$ \\
\hline Tiszáninneni református & $13+5$ & $\begin{array}{l}\text { Pest: } 10 \\
\text { Bécs, Debrecen, Nagykőrös, } \\
\text { Pozsony, Somogy vm., Szarvas, } \\
\text { Szepes, }\end{array}$ \\
\hline Pápai-komáromi református & $11+1$ & $\begin{array}{l}\text { Pozsony: } 5 \text {; Pest: } 2 \\
\text { Bécs, Debrecen, Győr katolikus } \\
\text { iskola, Sárospatak, Sopron }\end{array}$ \\
\hline $\begin{array}{l}\text { Dunamelléki-alföldi } \\
\text { református }\end{array}$ & $1+1$ & Pápa, Sárospatak: 1-1 \\
\hline $\begin{array}{l}\text { Észak-magyarországi } \\
\text { evangélikus }\end{array}$ & $11+1$ & $\begin{array}{l}\text { Pest: 6; Bécs: } 2 \\
\text { Debrecen, Mezőberény, Po- } \\
\text { zsony, Sopron }\end{array}$ \\
\hline Pozsonyi evangélikus & $2+15$ & $\begin{array}{l}\text { Pest: } 9 \\
\text { Bécs, Debrecen, Délvidék, } \\
\text { Kolozsvár, Pápa, Sárospatak, } \\
\text { Sopron }\end{array}$ \\
\hline Nyugat-dunántúli evangélikus & $4+4$ & $\begin{array}{l}\text { Pest: 4; Délvidék: } 2 \\
\text { Szarvas: } 1\end{array}$ \\
\hline $\begin{array}{l}\text { Szarvasi-mezőberényi } \\
\text { evangélikus }\end{array}$ & 2 & Selmec, Sopron: $1-1$ \\
\hline
\end{tabular}

Forrás: a szerző saját szerkesztése 